\title{
The risk of metacommunication to manage interactional trouble in online chat counseling*
}

\author{
Margot Jager (Groningen) ${ }^{* *}$ and Wyke Stommel (Nijmegen)
}

\begin{abstract}
The main handbook on online counseling used in the Netherlands recommends counselors to use metacommunication, i. e. to state what happens during the interaction, in case of interactional trouble. The aim of this study was to explore this interactional strategy by describing how counselors may use metacommunication to respond to interactional problems in online counseling of the "helpline" type (single chat sessions). Data were derived from a corpus of 197 sessions of the Dutch information chat service on alcohol and drugs and 348 sessions from a Dutch general chat help service. The theoretical and analytical framework of (digital) conversation analysis (CA) was used to analyze the data. The analyses show that metacommunication is used, but only rarely. Clients tend to log out from problematic sessions, often even before the counselor is able to identify interactional trouble at all. This means online counselors operate under the constant risk of clients' disengagement. Second, we identified and described three metacommunicative practices counselors use to respond to problematic interaction: 1) Self-criticizing; the counselor is regretting (s)he was not able to help due to a lack of useful advice or to the boundaries of the institutional context. This strategy seems to elicit client acknowledgement followed by an aligned closing; 2) Accusing: the counselor is questioning the client's advice recipiency. This strategy seems to elicit even more client resistance. 3) Explaining: the counselor explains the institutional tasks and responsibilities and/or suggests the client has unrealistic expectations. We conclude that although metacommunication can be useful to restore the relationship with the client when it is apologetic, it can also be counterproductive to deal with problematic interaction when the counselor questions the client's willingness or ability to accept the advice. For this reason, our analysis warrants the advice to avoid metacommunication as a strategy in single session counseling.
\end{abstract}

\section{$1 \quad$ Introduction}

Online counseling is considered a valuable alternative to face-to-face treatment, and seems to be as effective as traditional forms of counseling (Fukkink/Hermanns 2009; King et al. 2006a, 2006b; Rochlen et al. 2004). However, a need remains for stronger empirical evidence to es-

\footnotetext{
* We are grateful to the Netherlands Foundation for Mental Health which funded the research project resulting in this article. We also thank the Trimbos Institute and Korrelatie for collaborating with us in this study.

** When this research was done, Margot Jager was affiliated to the Radbout University, Nijmegen, Netherlands.

Linguistik online 87, 8/17 - http://dx.doi.org/10.13092/lo.87.4179
}

CC by 3.0 
tablish efficacy and effectiveness and to better understand the unique mediating and facilitative variables of various types of online counseling processes (Richards/Viganó 2013). In the Netherlands, a growing number of services provide information and advice through text based chat sessions, accessed through websites. This form of counseling is characterized by it being online, anonymous, time-constrained, and usually without follow-up. The interactional context of chat counseling is likely to present clients and counselors with interactional challenges specific to this mediated counseling situation. For this project, we collaborated with the Dutch information chat service on alcohol and drugs (hosted by Trimbos) and a Dutch general chat help service (Korrelatie). These services have the purpose of providing the general public with accurate information and advice. The question we analyze in this article is how counselors manage interactional trouble in their chat session by using metacommunication as a strategy. We show that the use of metacommunication in actual chat counseling sessions creates a number of risks. For example, when the counselor questions the client's willingness or ability to accept the advice, this elicits more resistance rather than advice acknowledgement. This type of metacommunication is severely face-threatening and further distorts the counseling relationship.

In this paper we describe three metacommunicative practices counselors use to respond to problematic interaction: 1) Self-criticizing; the counselor is regretting (s)he was not able to help due to a lack of useful advice or to the boundaries of the institutional context; 2) Accusing: the counselor is questioning the client's advice recipiency; 3) Explaining: the counselor explains the institutional tasks and responsibilities and/or suggests the client has unrealistic expectations. Before we report about the analysis of these metacommunicative practices in more detail, we first give an overview of the literature regarding online counseling, providing and receiving advice, and metacommunication related to the stocks of interactional knowledge, and describe the data and methods that were used.

\section{$2 \quad$ Literature review}

\subsection{Online counseling}

Compared to more traditional counseling environments, i. e. face-to-face or on the telephone, professionals working at chat services are confronted with challenges that are inherent to the online environment in which the interaction takes place. Various studies of online counseling interaction have examined the intricate relation between medium and counseling in recent years (for an overview, see Lamerichs/Stommel forthcoming). In this article, we present an analysis of professional chat interaction in counseling services that have the purpose of providing the general public with accurate information and advice. For reasons of space, we have singled out one study for detailed introduction as it studies professional chat interaction in the same counseling service, and because it was the indirect reason for the analysis we present in this article. The study compared the text-based chat and the telephone counseling of the Dutch information service for questions about alcohol and drugs. One of the findings was that closing a counseling session is more difficult in chat interaction than over the telephone (Stommel/Te Molder 2015). Both in chat and on the phone it is the client who initiates the interaction by seeking information or advice from the counselor, which implies that the client is also the one who closes the interaction. According to social norms, (s)he is also the one 
who has the epistemic rights to acknowledge whether sufficient information or advice has been given. Therefore, the participant norm is that it is the client who initiates the closing of a counseling session to make minimal imposition on the other speaker, in this case the counselor (Antaki 2002; Sacks 1992). In telephone counseling, clients overwhelmingly initiate closing by acknowledging the advice, but in chat counseling clients sometimes withhold a response to the advice or respond minimally ("okay"). In those cases, counselors pose questions like "can you work with this?" and "have I answered your questions?" to receive a (more explicit) advice acknowledgement from the client and thus to terminate the session (Stommel/Te Molder 2015). This implies the relation between advice acknowledgement and (pre-)closing is not just a co-occurrence; rather, the participants treat advice acknowledgement as a precondition for closing. More specifically, when clients do not overtly acknowledge or appreciate the advice, counselors are confronted with the question how to close off the session. For this reason, Stommel and Te Molder (2015) suggest that the counselor's position in online chat counseling is interactionally more fragile than the client's, at least at this point. From a client perspective, one of the affordances of text chatting is that the advice can be more easily resisted.

\subsection{Providing and receiving advice}

Seeking help and providing advice have been discussed in the literature as social actions that are negotiated interactionally and that are socially accomplished (Butler et al. 2010; Edwards/Stokoe 2007; Firth/Emmison/Baker 2005; Hepburn/Potter 2007; Heritage/Sefi 1992; Kinnell/Maynard 1996; Limberg/Locher 2012; Whalen/Zimmerman/Whalen 1988). The participants in their interaction orient to the overarching institutional goal of providing help in the form of information and/or advice. They mainly do so through their actions and the way they design these actions. In the course of these actions, the participants also jointly orient to their separate roles and responsibilities as help seeker and help provider. These separate roles implicate an asymmetrical counseling relationship. By offering advice, counselors display knowledge and expertise the client (advice recipient) is assumed not to have (Heritage/Sefi 1992).

When an advice is given the projected next turn is acknowledgement (preferred) or rejection (dispreferred). When advice is not acknowledged, it may be rejected explicitly, but when the advice is not acknowledged explicitly (enough) or soon (enough), this also implies advice resistance. In text-based chat sessions pauses between posts are much longer than the usual silences between spoken turns, and their nature is different: Users may be typing or repairing typed text (García/Jacobs 1999; Meredith/Stokoe 2014), they may be involved in multiple (chat) conversations and other activities at the same time (multitasking), or the Internet connection may be slow. However, the multi-interpretability of pauses seems to have different consequences for counselors and clients. For example, only a counselor may interpret a long pause as advice resistance. Counselors may then elaborate on their advice to create a new space (compare transition-relevant-place in spoken interaction) for the client to acknowledge the advice (Kinnel/Maynard 1996), or post pre-closing questions such as "have I answered your question?" or "can you work with this?" (Stommel/Te Molder 2015).

Stommel and Te Molder (2015) found that counselors topicalize (apparent) advice resistance in some way very rarely. Surprisingly, the main handbook on online counseling used in the 
Netherlands (Schalken et al. 2013) recommends counselors to use metacommunication, i. e. to state what happens during the interaction, when clients show signs of advice resistance. In the literature on (psycho)therapy, metacommunication has also been discussed, primarily as a strategy to manage "ruptures" in the therapeutic alliance (cf. Binder/Strupp 1997; Elliot et al. 2011; Geller/Greenberg 2002; Lietaer 1993). ${ }^{1}$ There seems to be a gap between counseling instructions and practice.

\subsection{Metacommunication and the stocks of interactional knowledge}

Metacommunication can be defined as what we do when we reflexively talk about talk for some pragmatic purpose (Verschueren 1999). Synonyms used for metacommunication include metatalk (Schiffrin 1980) and metadiscourse (Craig 2005). The role of metacommunication in our day to day interactions depends on social and cultural aspects and may be related to specific settings: psychotherapy is pre-eminently characterized by metatalk (Schiffrin 1980). It has been claimed more generally that there is currently a pervasive interest in metadiscourse in social interaction due to our cultural preoccupation with communication (Craig 2005). The fact that recent counseling protocols like Schalken et al. (2013) include a paragraph on metacommunication (Van Gemert/Van Hoogenhuyze 2013) as a counseling strategy may be considered a result of this.

Metacommunication comprises a large set of communication practices that are employed for a variety of functions and purposes in social interaction. For example, it may be used to structure the talk at hand ("at the beginning you said..."), explicate an interactional act ("I would advise you to...”), organize participants' availability (“are you still there?"), or evaluate aspects of the preceding interaction ("If you don't respond to my questions I cannot help you") (cf. Schriffrin 1980; Van Nijnatten 2006). Additionally, metadiscursive linguistic strategies contribute to relationship and identity building. However, Gordon/Luke (2016: 29) pointed out that the relational effect of the use of metadiscourse is not straightforward (cf. Tannen 1994). For instance, talking about how counselors-in-training want to be or are addressed by their clients can enhance their (developing) professional identity but also challenge it. The relational function of metacommunication is relevant to our analysis of interaction between counselors and clients as this relationship is asymmetrical and characterized by institutional goals such as advice giving.

Another function which is particularly relevant for our study is the use of metacommunication to overcome (communication) problems. Very basically, this function can be observed in utterances like "we should talk" (Craig 2005; see also Buttny 2010). Such utterances acknowledge there is a problem and propose talk as a solution or way to deal with the trouble.

Although metadiscourse has been analyzed in the context of counseling training (Gordon/Luke 2016), to our knowledge previous research has not focused on the interactional effects of metacommunication in counseling and with the specific focus of overcoming communication problems. The Dutch handbook on online counseling (Van Gemert/Van

\footnotetext{
${ }^{1}$ A workshop with online counselors was organized on the occasion of Stommel and Te Molder's (2015) research on the Dutch information service on alcohol and drugs. During this workshop, the counselors themselves claimed to use metacommunication in case of client resistance.
} 

interactional trouble in online chat counseling

Hoogenhuyze 2013), which is used to train online counselors in the Netherlands, describes when metacommunication should be used and how it should be used:

Use metacommunication in case the session does not run smoothly; step out of the content and discuss the course of the interaction.

(Van Gemert/Van Hoogenhuyze 2013: 94; our translation)

[...] take a distance from the content and talk about the course of the conversation. Name which pattern you notice in the interaction.

(Van Gemert/Van Hoogenhuyze 2013: 93; our translation)

The handbook provides the following example:

Co: You've been asking what you should do several times now while I just asked you a question. Co: It seems you don't like me asking these questions?

(Van Gemert/Van Hoogenhuyze 2013: 95; our translation)

In this example, the counselor steps back from the content and discusses the interaction itself. In the first post, the counselor describes the preceding interaction in terms of interactional activities; the client repeatedly asked something while an answer to the counselor's question was interactionally relevant and withheld by the client. In her second post, the counselor enquires if the client does not like the counselor's questions, which is formatted as a declarative question (the question mark renders it a question rather than a "noticing") projecting confirmation. Thereby, the counselor questions the client's counseling recipiency.

Peräkylä/Vehviläinen (2003) propose that assumptions of useful interactional strategies (such as metacommunication) may be seen as constituting a Stock of Interactional Knowledge (SIK). SIKs can be found in professional texts, in training manuals, and in written and spoken instructions delivered in the context of professional training and supervision. Peräkylä/Vehviläinen (2003) propose that Conversation Analysis (CA) may (i) falsify or correct assumptions that are part of a SIK, (ii) provide a more detailed picture of practices that are described in a SIK, (iii) add a new dimension to the understanding of practices described by a SIK, or (iv) provide the description of practices not provided by a very abstract or general SIK. By making individual solutions to general interactional problems (resulting from general institutional goals) more explicit, conversation-analytic research can contribute to a better understanding of these SIKs, which in turn could lead to an improvement in both the day-to-day practice of online counseling and the teaching of specific conversational techniques to prospective online counselors.

This study uses (digital) conversation analysis (Giles et al. 2015; Hutchby/Wooffitt 2008) to examine how counselors use metacommunication in response to interactional trouble in online chat counseling. We analyze metacommunication in the context of interactional trouble, with the aim of understanding how this interactional strategy actually works.

\section{$3 \quad$ Data and methods}

\subsection{Institutional context}

Eurostat (2017) reported that in $201697 \%$ of the Dutch population had Internet access, one of the highest percentages in Europe (average of $85 \%$ ). Of all people that were active on the 
Internet, $58 \%$ used the Internet for health purposes. For this project, we collaborated with the Dutch information chat service on alcohol and drugs (hosted by Trimbos) and a Dutch general chat help service (Korrelatie). These services have the purpose of providing the general public with accurate information and advice.

The Trimbos Institute reported that 1.585 serious chat sessions took place on their online platforms in 2015, which is an increase of $18 \%$ compared to 2014 and $30 \%$ compared to 2013. The average time of a chat session was 18 minutes; the protocol recommends a maximum duration of 45 minutes. On the home pages of their websites (www.alcoholinfo.nl and www.drugsinfo.nl) visitors are invited to call, chat or email. The chat service can be reached via the websites on week days between 13PM and 17PM. The chat window is one on one, counselors are randomly assigned to new visitors, and no explicit statements about anonymity are mentioned.

Korrelatie reported that, in 2015, 17,000 people reached out to Korrelatie for anonymous help. $42 \%$ of these contacts were via chat, which means 7.140 chat sessions took place on their online platform. Korrelatie also reported an increase of client contacts via chat compared to e-mail and telephone from $21 \%$ in 2013 to $34 \%$ in 2014 and $42 \%$ in 2015. The guidelines for a Korrelatie chat session indicate a maximum duration of 30 minutes. However, online counselors can decide whether or not to adhere to this time constraint. The homepage of the website (www.korrelatie.nl) presents a direct link to the chat service which is available on week days between 9AM and 17:30PM. When visitors start a chat session they are first contacted by the "front desk" who provides a link to a page on the organization's rules and privacy statement. When an online counselor is available (s)he will be added to the chat session and the "front desk" leaves the session. It is possible for visitors to indicate a preference for a specific counselor.

Online chat counseling is usually demand-driven; the client seeks information or advice. Online counselors working at the chat services of Trimbos and Korrelatie are trained for these tasks by their employer. The training from both institutions is based on the handbook from Schalken et al. (2013). Most counselors have a background in social work or psychology. The websites of these organizations state information provision and advice giving as their main tasks. It is therefore not surprising that both clients and counselors usually display an orientation towards requesting information or advice as the main interactional activity.

The study was approved by the ethics committee of the Faculty of Arts, Radboud University, under the conditions that the chats did not include information that could lead to the actual participants and that all researchers had signed a vow of secrecy.

\subsection{Data and analytic procedure}

The data were derived from a corpus of 197 sessions of the Trimbos Institute and 348 sessions from Korrelatie. These were single sessions on a broad range of topics. We selected problematic chat sessions with metacommunication from this data set following three steps. First, we excluded chat sessions that lacked interaction between a client and a counselor. This often occurred at the general chat help service when clients were told by the "front desk" to wait for a counselor to become available. Often these clients logged out before the session started. Second, we selected sessions with "unsmooth"/problematic interaction. Inclusion criteria in 
this step were: client's non-responses, long pauses, overt resistance, lack of advice acknowledgement, and unilateral closing. We also used our intuition by asking ourselves the question: does the counselor have to do more work than usually for the interaction to run smoothly? All sessions were screened for problematic interaction by three people (the first author and two undergraduate students). When there was doubt or disagreement, the first author read the chat session again and decided whether it had to be included or not. These first two steps resulted in a collection of 49 sessions of the Trimbos Institute (25\% of the total Trimbos collection) and 57 sessions from the general chat help service (16\% of the total Korrelatie collection).

Of the chat sessions that we identified as problematic, in 30 sessions of the Trimbos Institute $(61 \%)$ and 30 sessions of Korrelatie (53\%), the client disengaged from the interaction. Because these sessions did not include metacommunication, we excluded them from our data set. However, disengagement may provide an explanation for the rare use of metacommunication in our data. Therefore, we will discuss client disengagement without metacommunication in some detail here. Previous studies of chat closings (Markman 2009; Raclaw 2008) analyzed ways of closing chats with more archetypical sequencing and with automated triggers. Closings tended to be designed in alignment, being initiated with a preclosing which received an aligned response. In contrast, in our data some closings are disaligning actions, hence they are "premature". Premature closing occurs when a different type of action (e. g. an answer to a question) is relevant but absent. In lieu of the relevant action, the client produces an automated trigger ("client has left the chat") or remains silent upon which the counselor produces an automated trigger ("chat is ended"). Excerpt 1 shows an example of the latter variant.

The client's reason for starting the session was that her boyfriend had a bad trip and she did not know what to do. One of her first posts was help me, which gave the session an acute nature. Excerpt 1 begins with the counselor's question about the situation, which is followed by advice in line 3.

\section{Excerpt 1}

Alcohol- and drugs service (Trimbos), chat T38

$1 \quad$ [15:21:18] Co: oké, is hijzelf ook een paniek?

'okay, is he freaking out too?'

2

(0.36)

3 [15:21:54] Co: Vraag:

4

Wat kun je doen bij een bad trip?

Antwoord: [regels weggelaten-lijst met 12 adviezen]

'Question:

What can you do in case of a bad trip ${ }^{\mathrm{a}}$ ?

Answer: [lines omitted - list of 12 pieces of advice]'

6

$(0.02)$

$7 \quad[15: 21: 56] \quad \mathrm{Cl}: \quad \mathrm{Nee}$

'No'

$(0.30)$

$9 \quad[15: 22: 26]$

Co: hij zal het moeten uitzitten, is heel vervelend maar enige wat je kunt doen is zelf rustig blijven en hem te kalmeren

'he will have to wait it out, that's very annoying but the only thing you can

ISSN 1615-3014 


$\begin{array}{lll} & & \begin{array}{l}\text { do is stay calm yourself and calm him down' } \\ (0.56)\end{array} \\ 11 & {[15: 23: 22] \quad \text { Co: } \quad \begin{array}{l}\text { wat nee? } \\ \text { 'what do you mean no?' } \\ \end{array}} \\ 13 & (1.48) \\ 14 & {[15: 25: 10]} & \text { [Chat is ended. }]\end{array}$

${ }^{\text {a }} \mathrm{A}$ bad trip (drug-induced temporary psychosis or psychedelic crisis) is a disturbing experience typically associated with use of one or more of various hallucinogens of types including psychedelics.

The question whether the client's boyfriend is freaking out does not receive an answer for 0.36 seconds. Then, the counselor seems to post general advice on what to do in case of a bad trip into the chat session - presumably copied from a website or local information document. The client's nee ('no') in line 7 responds to the question in line 1 . This becomes evident by the time stamps in lines 3 and 7 which are only 2 seconds apart, indicating simultaneous typing. The counselor, however, does not take this up and rephrases her advice in a colloquial format (lines 9-10). Then, for almost a minute, the client neither responds to, nor acknowledges the advice. This is problematic from the perspective of the counselor; advice acknowledgement is usually pursued in online counseling of the "helpline" type (single chat sessions) (Stommel/Te Molder 2015). In this case, the counselor seems to look for where she might have missed something and initiates repair (Meredith/Stokoe 2014; Schegloff 1992) of the no response (line 7). However, the client then disengages, having received advice, but not having acknowledged, accepted or, for that matter, rejected it. Hence, she leaves the session "unclosed". The counselor arguably has tried to "restore" the session, but failed.

Cases like Excerpt 1 could be easily explained by many other things than the quality of the counseling. Clients could be multitasking, be called away, have internet connection problems, etc. However, overall there seems to be a pattern that problematic interaction increases chances that a client logs out prematurely.

For our analysis, with an interest in understanding how counselors use metacommunication to respond to interactional trouble, this meant that after excluding all sessions where the client disengaged from the session without any explicit warning and no metacommunicative strategies were used, we were left with 46 sessions. The third step was to identify those sessions in which counselors used metacommunication, i. e. the counselor steps out of the content and discusses the course of the interaction (Van Gemert/Van Hoogenhuyze 2013). This resulted in a collection of 15 sessions from the chat service on alcohol and drugs and 14 sessions from the general chat help service. The 17 sessions with interactional trouble but no metacommunication that were excluded in this step involved hoaxing, transgressive questions (e.g. sexual requests), language barriers, or breaking of organizational rules, or the counselor simply "ignoring" trouble (e. g. using a pre-closing question).

\subsection{Analytical approach}

We used the theoretical and analytical framework of (digital) conversation analysis (CA) to examine the use of metacommunication in response to interactional trouble in online counseling (Giles et al. 2015; Hutchby/Wooffitt 2008). Traditionally CA is a data-driven research approach but in recent years researchers have been looking for ways to use CA also as an ap- 
proach to answer specific questions derived from theory and practice (Antaki 2011). The analysis reported in this article is the result of an iterative analytical process involving data, theory, and the SIK on metacommunication described in the handbook on online counseling (Van Gemert/Van Hoogenhuyze 2013).

\section{$4 \quad$ Analysis}

We observed three recurrent metacommunicative practices. ${ }^{2}$ The first practice involves the counselor regretting not being able to or not having been able to help. The second practice involves the counselor questioning the client's counseling recipiency. The third practice is different in the sense that it is the client who first initiates metacommunication, usually by accusing the counselor of not providing sufficient information or advice. The counselor, in response, uses metacommunication to explain the institutional boundaries, thereby implicitly accusing the client of having unrealistic expectations.

\subsection{Regretting inability to help}

The first practice we identified was the counselor regretting not being able to, or not having been able to help. This strategy usually occurred towards the end of a chat session. Excerpt 2 shows an example of the counselor accounting for her own lack of counseling competence. The client is a 36 years old woman who has problems with her husband; she wants to separate but cannot afford it. Her initial question was how she could live with him in one house, while he is verbally aggressive and unfaithful to the arrangements they made. The counselor has advised her to leave the house if it is impossible to live with him, but the client has not accepted this advice, which brings the counselor to ask: could you formulate your question to me once more, [name client]? After some more posts back and forth the client writes: now that I am typing it I see it is a bit of a difficult question. And I realize I am the victim here. The interaction continues with posts about possible explanations of the husband's aggression and treatment he received. Excerpt 2 begins 44 minutes after the start of the chat session, which is already beyond the time limit.

\section{Excerpt 2}

General help service (Korrelatie), chat K414

1 [3:27:37] Co: [NAAM], we moeten zo langzamerhand gaan afsluiten. We zijn over de tijd

2 heen. Ik heb het gevoel dat ik je niet echt heb kunnen helpen. We hebben

$3 \quad$ elkaar niet steeds begrepen heb ik het idee.

'[NAME], little by little we have to start closing off. We have gone over time. I have the feeling that I haven't really been able to help you. We haven't always understood each other I think.'

$4 \quad(0.33)$

5 [3:28:10] Co: Ja, over PTSS. Je kunt ook info zoeken op internet over PTSS en kijken of je

6 iets herkent.

\footnotetext{
${ }^{2}$ We have no reason to assume that counselors use a particular metacommunicative practice idiosyncratically. In the Korrelatie sample counselors were identified through a unique code. The 14 chat sessions with metacommunication from this set included 11 different counselors and three chat sessions from one counselor, but (s)he used various metacommunicative practices.
} 
'Yes, about PTSS. You can search for info on PTSS on the internet and see whether you recognize something.'

$7 \quad(0.04)$

$8 \quad$ [3:28:14] Cl: ik heb er wel wat aan gehad

'it did help me though'

$9 \quad(0.25)$

10 [3:28:39] Cl: over praten is al heel fijn

'it's already great to talk about it'

11

(0.06)

12 [3:28:45] $\quad \mathrm{Cl}: \quad$ jullie doen goed werk

'you (pl) are doing a good job'

13

$(0.01)$

$14 \quad[3: 28: 46]$

Co: $O$ gelukkig maar. Als het moeilijk wordt voor je, kun je gerust nog eens chatten of bellen.

'O fortunately. When it gets hard on you, feel free to chat or call us again.'

$16 \quad[3: 29: 00]$

$\mathrm{Cl}: \quad$ ja weet $i k$

'yes I know'

17

(0.13)

$18 \quad[3: 29: 13]$

Cl: ik ga even verder met de informatie die je me geven hebt

'I'll just go ahead with the information you gave me'

19

(0.16)

20 [3:29:29]

Co: Dat is goed. Kan ik afsluiten nu?

'That's fine. Can I shut down now?'

21

(0.02)

22 [3:29:31]

$\mathrm{Cl}$ : bedankt voor het gesprek

'thanks for the conversation'

23

(0.05)

$24 \quad[3: 29: 36]$

$\mathrm{Cl}: \quad$ jullie zijn toppers

'you [pl] are tops'

25

(0.05)

$26 \quad[3: 29: 41]$

Co: Graag gedaan.

'You're welcome.'

27

(0.07)

28 [3:29:48]

Co: Ik sluit af. Akkoord?

'I shut down. Agreed?'

29

(0.04)

30 [3:29:52]

$\mathrm{Cl}$ doei doei

'bye bye'

31

(0.04)

32 [3:29:56]

*** Co has left ***

(2.11)

34 [3:32:07]

*** $\mathrm{Cl}$ has left ***

In line 1 the counselor initiates closing of the chat session due to time constraints (referring to the maximum of 30 minutes for a session as announced on the website). In this same post, she also evaluates the session using metacommunication, which turns out to be a rather selfdeprecating assessment, as she writes $I k$ heb het gevoel dat ik je niet echt heb kunnen helpen 
('I have the feeling that I haven't really been able to help you'). Thereby, she implicitly devaluates her own counseling competence. In a next sentence, she seems to shift from discussing her counseling competence towards shared "blame" (we hebben elkaar niet steeds begrepen ('we haven't always understood each other') of an apparently unsuccessful chat session. After another post of the counselor that is a response to an earlier suggestion of the client that her husband might suffer from PTSS, the client states: ik heb er wel wat aan gehad ('it did help me though') (line 8). This is a direct response to the counselor's metacommunicative post in lines 1-3. By using wel ('though') the client seems to deny not just the counselor's competence but also the suggested lack of mutual understanding. She explains this by positively evaluating the "talking" (line 10), which implies that her advice seeking question at the start of the session has been replaced with the request to talk about it, which is exactly what she got from the counselor. In line 12, the client further accounts for her positive evaluation of the chat session by complimenting the chat service in general using the plural pronoun jullie (English pl. 'you'). In this example, the counselor's strategy of self-deprecating leads to several posts of the client denying the counselor was not able to help. In this case the selfdeprecating strategy of the counselor clears the floor for an aligned closing of the session. The participants use nine more posts (lines 16-34) to collaboratively close the session.

\subsection{Questioning the client's advice recipiency}

The second practice we identified was the counselor questioning the client's counseling recipiency. Excerpt 3 shows an example. The client presented himself as a lecturer whose student has been hospitalized at one of the institutions for addiction care which man the chat service. He wants to write the student a postcard and asks for the room number, but the counselor has no access to this kind of information. The client has just given the name of the student when Excerpt 3 starts.

\section{Excerpt 3}

Alcohol- and drugs service (Trimbos), chat T68

1 [15:53:43] Co: dat kan ik helaas ook niet zien. client gegevens kunnen maar een paar mensen inzien ivm privacy.

'unfortunately I can't see that either. only a few people have access to client information for privacy reasons.'

3

4

5

6

8

$9 \quad[15: 58: 37]$

10

11

$12 \quad[15: 59: 28]$
(0.56)

[15:54:39] Co: [the counselor makes a proposal - data omitted at the request of the organization]

[15:57:15] Co: [NAAM], ben je daar nog?

'[NAME], are you still there?'

(1.22)

Co: $\quad$ ik probeer je te helpen maar als ik geen reactie krijg dan gaat dat moeilijk

'I am trying to help you but if I don't get a response that's difficult'

$(0.51)$

[Chat is ended by visitor.] 
The counselor rejects the client's request for information and provides a reason for it (lines 12). When this rejection does not receive a reply, the counselor proposes a further action, making relevant a response. However, a response does not follow for over two minutes (line 6). Then, the counselor asks whether the client is still engaged with the session. After another pause of more than a minute, in lines 9-10 the counselor uses metacommunication to "accuse" the client of not fulfilling his interactional role: ik probeer je te helpen maar als ik geen reactie krijg dan gaat dat moeilijk ('I am trying to help you but if I don't get a response that's difficult'). This post also does not receive a client response and after 51 seconds the client disengages from the chat session by logging out.

Excerpt 4 shows another example. The client is a 17-year old girl who explains that she has found out that her father is addicted to smoking marihuana. He is very aggressive and denies everything. Her question is: what should I do? . The counselor immediately posts extensive advice aimed at the girl: she should seek help to discuss how to deal with this situation, and her mother should be the one who solves things with her husband (the client's father). The client rejects this advice with: I don't need help, he needs help I would think!! After another advice-resistance sequence focusing on the mother's role, the client poses a concrete, practical question, suggesting what the family needs is an external service to take care of the problems with her father. The counselor only loosely responds to the client's question, and posts another piece of advice. This is where Excerpt 4 starts.

\section{Excerpt 4}

Alcohol- and drugs service (Trimbos), chat T63

$\begin{array}{ll}1 \text { [13:34:53] Co: } & \text { ook voor je moeder zijn er bijeenkomsten hoe om te gaan met een } \\ & \text { verslaafde partner bijvoorbeel. google bijvoorbeeld eens op cokevanjou } \\ & \text { die doen er ook het een en ander mee en kunnen handige tips geven } \\ & \text { 'for your mother there are also sessions on how to deal with an addicted } \\ & \text { partner for example. google for instance to cokevanjou they also do with } \\ & \text { this and can give useful advice' }\end{array}$

4

5
(0.36)

[13:35:29] Co: snap je een beetje wat ik bedoel en waarom een gesprek

het beste zal werken?

'do you understand a bit what I mean and why a session would work best?' (1.25)

[13:36:54] Cl: Ja ik begrijp dat $u$ dit allemaal moet zeggen, maar $u$ wilt niet weten hoeveel jaren we al met hem hierover gesprekken voeren, en de laatste tijd kun je geen normaal gesprek dus wat niet over drugs gaat met hem bespreken 'yes I understand that you have to say all of this, but you don't know how many years we are already discussing this with him, and lately you can't have a normal conversation with him so which is not about drugs'

(2.13)

[13:39:07] Co: ik moet geen dingen zeggen hoor, ik probeer jullie te helpen. als jullie al lang gesprekken hierover voeren vind ik dat het vanuit je moeder ook eens consequemties moet hebben. vanaf nu niet meer blowen of anders gaat hij het huis uit. en bij agressie een keer de politie inschakelen. je moet je vader duidelijk maken dat het echt niet meer gepikt gaat worden 'I don't have to say things, I'm trying to help you [pl]. if you [pl] are al-

ISSN 1615-3014 
ready discussing this for a long time I think that your mother should impose consequences. from now on no smoking anymore or else he leaves the house. and in case of aggression call the police for a change. you have to make clear to your father that it is really not accepted anymore' (1.06)
[13:40:13] Co: ik weet dat dat makkeliker gezegd dan gedaan is, maar mensen die nemen verslaafd zijn hebben dat echt nodig want anders veranderen ze niet en ze de ruzies voor lief maar gaan gewoon door

'I know it is easier said than done, but people who take are addicted really need that because otherwise they won't change and take the arguments for granted but just go on'

\section{[13:41:57] Co: heb je hier nu wat aan en kom je er verder mee? \\ 'does this help you now and can you work with this?'}

\section{[13:42:38] Cl: Bedankt voor je hulp heb er alleen niks aan sorry \\ 'Thanks for your help just doesn't help me at all sorry'}

\section{[13:43:17] Co: dat vind ik jammer, wat had je dan verwacht ik heb je veel tips gegeven} toch?

'I regret that, what did you expect then I've given you lots of advice right?' (2.09)
Co:
http://www.XXX via deze link zou je vader zich kunnen aanmelden voor hulp, maar zover is hij denk ik (nog) niet 'http://www.XXX through this link your father could sign up for help, but I don't think he is ready for this (yet)'

In lines $1-3$, the counselor refers the daughter and her mother to an organization related to the Trimbos Institute where they can participate in group sessions from an addiction care institution. This is an external service but not a home service contrary to what the client desired. In lines 5-6, when the client has not acknowledged the advice, the counselor poses a question that elicits an advice acknowledgement as it heavily prefers yes as an answer. This format is similar to the pre-closing questions (for example: "Have I answered your question like this?") described by Stommel/Te Molder (2015). Alternatively, the counselor could have responded to the advice resistance here using metacommunication. In this case, an answer like "yes, thank you for the advice" would have initiated the closing. However, instead, in line 8 the client claims to understand the counselor has 'to say all this' ( Ja ik begrijp dat u dit allemaal moet zeggen), which disqualifies the counselor as a competent advice provider. She continues to resist the advice (even if she does not seem to refer to the advice to take part in a session).

Next, in lines $12-16$, the counselor attempts to reinstall her advice competence by denying she has to say things and making explicit her institutional goal: ik probeer jullie te helpen ('I'm trying to help you'). She goes on giving advice in directive formats using deontic modalities and imperatives. Note the client does not post a response now and non-response in this case bolsters the earlier advice resistance. In a further post (lines 18-20), the counselor accounts for her forceful advice in lines 12-16: ik weet dat dat makkeliker gezegd dan gedaan is, maar ('I know it is easier said than done, but'). Again, there is no uptake from the client. 
Then the counselor posts pre-closing questions of the type we saw earlier, initiating closing. The client thanks the counselor which is "doing advice recipiency", but also denies she has been helped, hence declaring the institutional goal has not been achieved. The counselor now uses metacommunication by "regretting" unsatisfying advice but also by questioning the client's advice recipiency and defending her own advice competence. This issue is not resolved and the session is not closed collaboratively (the counselor's post in lines 29-30 is the last one in this chat session).

\subsection{Explaining institutional tasks and responsibilities}

The third practice we identified was the counselor using metacommunication to explain the institution's tasks and responsibilities, thereby implicitly accusing the client of having unrealistic expectations. This practice occurs in response to allegations or complaints of the client, and is typically used in combination with other meta-communicative practices.

Excerpt 5 shows an example where the counselor refers to the organization's restricted tasks and goals as an account for not having been able to help in response to a complaint of the client. In this session the client is a 19-year-old man who is wondering whether he might have an alcohol problem. Already in his first post he expresses his doubts (I am not sure but...) and when the counselor asks why he thinks he might have an alcohol problem he refers to friends who addressed his drinking behavior. Before the start of this excerpt the session has been running for 35 minutes already (the protocol suggests a maximum duration of 45 minutes), and the counselor eventually provides advice by suggesting that the client may want to look at a website of the addiction care institution in his neighborhood and make an appointment there. This is where Excerpt 5 starts.

\section{Excerpt 5}

Alcohol- and drugs service (Trimbos), chat T71

$1 \quad$ [13:38:15] Co: Ik zou op de site kijken van de verslavingszorginstelling bij jouw in de buurt en daar een afspraak maken.

'I would look at a website of the addiction care institution in your neighborhood and make an appointment there.'

3

$4 \quad[13: 38: 29]$

5

$6 \quad[13: 38: 57]$ 7

8

$9 \quad[13: 39: 44]$

10
(0.14)

Co: Kun je hiermee verder?

'Can you work with this?'

$(0.28)$

$\mathrm{Cl}: \quad$ wil je het gesprek afkappen ofzo ?? het lijkt de heletijd dat je wilt stoppen ben je door je tijd ofzo??

'do you want to cut off the chat or something ?? the whole time it seems you want to stop are you running out of time or something??'

(0.47)

Co: De chat is een doorverwijsplek, excuses als je je afgekapt voelt dat is niet de bedoeling

'The chat is a place of referral, apologies if you feel cut off that is not the intention'

(0.42)

Co: $\quad$ Maar ik probeer een advies aan je te geven en mee te denken, dat kan als je daar op reageert. 

interactional trouble in online chat counseling

'But I try to give you advice and to think with you, which is possible if you respond to it.'

14

$15 \quad[13: 41: 01]$

16

$17 \quad[13: 43: 16]$

18

19

20

21

22 [13:44:04]

23

$24 \quad[13: 44: 23]$

25

$26 \quad[13: 44: 25]$

27

$28 \quad[13: 44: 30]$

29

30

$(0.35)$

$\mathrm{Cl}$ : oke, maar ik zit nu heel erg diep te denken

'okay, but I am thinking now very thoroughly'

(2.15)

Co: $\quad C l$, ik zou je graag verder helpen maar je reageert niet op mijn ideeen.

' $\mathrm{Cl}$, I would love to help you but you don't respond to my ideas.'

$(0.31)$

Co: $\quad$ De chat is een verwijsplek waar zoveel mogelijk mensen probeer op ideeen te brengen voor hulp.

'The chat is a place of referral where we try to give as many people as possible ideas for help.'

(0.17)

$\mathrm{Cl}: \quad$ oke maar ik luister wel naar wat je zegt

'okay but I do listen to what you say okay'

(0.19)

Cl: en ik ga met me therapeut

'and I am going to my therapist'

$(0.02)$

Co: Dat geloof ik ook.

'I do believe you.'

$(0.05)$

$\mathrm{Cl}$ : het er over hebben

'to talk about it'

$(0.11)$

[13:44:41] Co: Goed zo

'Very good'

The counselor's advice in lines 1-2 is, after a short pause, followed by a pre-closing question eliciting advice acknowledgement (Stommel/Te Molder 2015). This elicits the client to accuse the counselor of wanting to cut off the chat (lines 6-7). The counselor starts her metacommunicative response to the client's accusation by stating the main task of the chat service (referral), which is followed by an apology: De chat is een doorverwijsplek, excuses als je je afgekapt voelt dat is niet de bedoeling ('The chat is a place of referral, apologies if you feel cut off that is not the intention'). However, this apology is downgraded by transferring responsibility for the offense to the client; the counselor apologizes for the client's offended feelings and states that cutting off was not her intention. Next, the counselor provides an account (lines 12-13) explaining that it was his lack of response to her advice which lead to the preclosing move. This way, the counselor not only avoids taking responsibility for the client's feelings of offense, but even suggests that the client is the one who caused interactional trouble by not complying to the advisory nature of this particular institutional context. The client provides an account for his lack of recipiency (line 15), thereby treating the accusatory metacommunicative remarks of the counselor as legitimate. After another 2.15 minute pause the counselor makes another (accusatory) metacommunicative move by stating that she has good intentions, ik zou je graag verder helpen ('would love to help'), which she cannot fulfill due to the client's lack of responsiveness to her ideas. The client does not respond and the counse- 
lor again states the institution's tasks and responsibilities (lines 19-20). Now the client responds and acknowledges the advice the counselor gave earlier in the session (talking about it with his therapist). After this the counselor initiates closing which is collaboratively achieved (data not shown).

Excerpt 6 shows another example of a counselor explaining the institution's tasks to respond to a complaint from a client. Here, the client is less compliant than the one in Excerpt 5 and starts a negotiation of what the counselor has to offer. In this session the client is a 41-yearold woman who, already in her first post, provides a lot of information about her life and the problems she encounters. The main topics she addresses are her (disappointing) therapeutic history and her potential new job. Before the start of this excerpt the session has been running for over 30 minutes already, and the counselor eventually provides advice by suggesting that the client may want to look for some sort of coaching to help her in her new job instead of going for therapy. This leads to several posts in which the client rejects the advice and evaluates it as not new. This is where Excerpt 6 starts.

\section{Excerpt 6}

\section{General help service (Korrelatie), chat K163}

$1 \quad$ [11:12:21] Cl: En wat heeft het formuleren van doelen voor zin. Dat heb ik al miljoen keer gedaan. weet je Co ik begin in dit gesprek alleen maar bozer te worden. 'And what is the use of formulating goals. I've already done that a million times. you know Co I start to get even more angry in this conversation.' (0.25)

$\mathrm{Cl}$ : Dat geeft mij weinig vertrouwen voor weer een volgend therapeutisch contact.

'That gives me little faith in yet another therapeutic contact' $(0.35)$

Co: Ik heb het idee dat ik geen ruimte krijg van je om te helpen, misschien verwacht je meer van deze organisatie dan we je kunnen bieden. 'I have the feeling that you don't give me space to help you, maybe you expect more of this organization than we are able to offer.' (0.05)

$\mathrm{Cl}$ : Blijkbaar zit het er niet in om iets te kunnen met weer antwoorden op vragen

Wat heb je te bieden?

'What do you have to offer?' (three posts of the client are omitted in which she explains her previous [disappointing] relationships with therapists.) $(0.41)$

Co: We proberen hier te ondersteunen in het zoeken van oplossingen. Soms helpt het om tips te geven en soms helpt het om te onderzoeken waarom bepaalde dingen niet lukken. Ik heb het idee dat je al zo veel negatieve ervaringen hebt dat ik weinig ruimte krijg om met je mee te denken en op veel dingen die ik zeg word afgerekend. 

interactional trouble in online chat counseling

'We try to support in finding solutions here. Sometimes it helps to give advice and sometimes it helps to examine why certain things don't work out. I have the feeling that you've already had so many negative experiences that I get little space to think with you and am judged on many things that I say.' $(0.12)$

\section{Co: Ik neem je dat absoluut niet kwalijk, maar het is dan wel lastig} om je te helpen.

'I absolutely do not blame you for that, but it does make it difficult to help you.'

$(0.27)$

Cl: $\quad$ Ik krijg vragen die ik al eerder gekregen heb en tips die ik al onderzocht heb. 'I get questions that I already got before and advice that I have already considered.'

After this rejection of her advice in lines 1-5, the counselor uses metacommunication to accuse the client of not giving her space to help, thereby implicitly blaming her for not being a good advice recipient, i. e. if you ask for advice you should allow the counselor the opportunity to give advice. In the second part of the accusatory post (lines 7-8), the counselor suggests that the client has unrealistic expectations of what the organization has to offer: misschien verwacht je meer van deze organisatie dan we je kunnen bieden ('maybe you expect more of this organization than we are able to offer'). Thereby, she does not treat the client's accusation as directed to her personally but as inherent to the nature of the service. The client, in response, does not defend her advice recipiency, but initiates a discussion of the tasks and responsibilities of the counselor (as a representative of the organization). This way, she invites the counselor to explain herself, which is indeed what happens in lines 16-18. After a general description of the way things work, the counselor again accuses the client of not giving her enough space, and even to be judgmental on the things she says. After a short pause (line 21) the counselor downgrades her prior accusation by explicitly stating that she does not blame the client for the interactional trouble. However, the second part of her post is a butprefaced implicit accusation of the client making it difficult for her to fulfill her institutional role as help provider. In line 25 , the client then starts to explain herself, thereby treating the counselor's accusation as legitimate. The session goes on with several posts in which client and counselor further discuss what it is the client is looking for. The session is getting back on track and eventually has a positive collaborative closing.

The sessions in which the metacommunication stretches to a discussion of the nature of the particular service also always include accusatory posts with regard to advice recipiency. Overall, this strategy seems less disturbing for the counseling relationship, as it moves the discussion away from personal accusations.

\section{Discussion}

In this article we have described how counselors use metacommunication to respond to interactional problems in online counseling of the "helpline" type (single chat sessions). We found that metacommunication is used, but only rarely. Clients tend to log out from problematic sessions, often even before the counselor is able to identify interactional trouble at all. This means online counselors operate under the constant risk of clients' disengagement. 
Second, we identified and described three metacommunicative practices counselors use to respond to problematic interaction: 1) Self-criticizing; the counselor is regretting (s)he was not being able to help due to a lack of useful advice or to the boundaries of the institutional context. This strategy seems to elicit client acknowledgement followed by an aligned closing; 2) Accusing; the counselor is questioning the client's advice recipiency. This strategy seems to elicit even more client resistance. 3) Explaining; the counselor explains the institutional tasks and responsibilities, thereby implicitly accusing the client of having unrealistic expectations. Hence, each of these metacommunicative strategies contributes to the relationship between client and counselor, either restoring it or harming it further (cf. Gordon/Luke 2016). The three strategies are sometimes used in combination in one post, or step by step during the session.

The scarcity of metacommunication as a strategy to respond to interactional problems is surprising given the ritualized nature in which we use metadiscourse to restore (communication) problems (Craig 2005). It might be related to, or explained by, a number of aspects relevant to the medium and the setting. First, the online text-based medium creates the possibility or risk of disengagement. The client may be gone before the counselor has (taken) the chance to initiate a discussion on the course of the interaction. It seems that the affordance of logging out puts the client in a structurally more powerful position than the counselor. Second, counselors may be reluctant to use metacommunication because they are uncertain whether the client really is resistant towards the advice. After all, they have only typed words. Aspects that may help to detect resistance are absent in chat interaction; there are no voice and intonation, no facial expressions and body movements available to base their judgment on. Acting upon advice resistance seems delicate, probably partly because of its potentially accusatory nature. Therefore, counselors may be inclined to interpret silences and minimal acknowledgements in response to advice as related to the medium of chat rather than as resistant behavior. Third, acting upon advice resistance by topicalizing it (metacommunication) can harm the counseling relationship. Research on counseling and therapy has found that the client-counselor alliance is a major factor determining effectiveness of care (Duncan et al. 2010). In timeconstrained, anonymous, text-based online counseling such an alliance may be more difficult to establish, more easily ruptured, and harder to resolve. One reason for the lack of metacommunication to respond to interactional trouble in online counseling may be that it is highly face-threatening and therefore (unconsciously) avoided by counselors. Effective metacommunication presumes some level of established positive therapeutic alliance (Kiesler 1996). Research suggesting that metacommunication may be an effective strategy to manage "ruptures" in the therapeutic alliance is all based on longer counseling trajectories (cf. Binder/Strupp 1997; Elliot et al. 2011; Geller/Greenberg 2002; Lietaer 1993). Online counselors only have a single session to build an alliance and to solve alliance ruptures when these occur. When initiating metacommunication, counselors need to figure out how to topicalize the (disrupted) interaction, while at the same time avoiding an irrevocable alliance rupture. Viewing the identified practices as metacommunication, we conclude that metacommunication can be useful to restore the relationship with the client when it is apologetic. A minor drawback of this strategy may be that it reduces the asymmetry between the counselor and the client. This may even undermine the counselor's identity as an expert and therefore a competent and 
reliable advice giver. By using apologetic metacommunication the counselor's identity is reduced to someone who is at the most able to offer a listening ear.

The analysis shows that metacommunication can also be counterproductive to deal with problematic interaction. On this basis, it seems fair to question the SIK of metacommunication in single session online counseling. More precisely, our analysis corrects the conviction that metacommunication is an effective strategy in online counseling. It can be, but it frequently is not. This happens when the counselor questions the client's willingness or ability to accept the advice, which is a reproach. This type of metacommunication is severely face-threatening and elicits more resistance rather than advice acknowledgement. Hence, it further distorts the counseling relationship. An addition related to the risk of metacommunication seems legitimate. Metacommunication may be perceived as accusatory, which could disturb the fragile counseling relationship or it may undermine the counselor's expertise and counseling competence. For this reason, our analysis warrants the advice to avoid metacommunication as a strategy in single session counseling.

\section{References}

Antaki, Charles (2002): “Lovely”: Turn-initial high-grade assessments in telephone closings". Discourse Studies 4/1: 5-23. doi: 10.1177/14614456020040010101.

Antaki, Charles (ed.) (2011): Applied Conversation Analysis: Intervention and Change in Institutional Talk. New York: Palgrave Macmillan.

Binder, Jeffrey/Strupp, Hans (1997): “Negative process”: A recurrently discovered and underestimated facet of therapeutic process and outcome in the individual psychotherapy of adults". Clinical Psychology: Science and Practice 4/2: 121-139. doi: 10.1111/j.14682850.1997.tb00105.x.

Butler, Carly/Potter, Jonathan/Danby, Susan/Emmison, Michael/Hepburn, Alexa (2010): “Advice-implicative interrogatives building 'client-centered' support in a children's helpline”. Social Psychology Quarterly 73/3: 265-287. doi: 10.1177/0190272510379838.

Buttny, Richard (2010): "Citizen participation, metadiscourse and accountability: A public hearing on a zoning change for Wal-Mart". Journal of Communication 60/4: 636-659.

Craig, Robert (2005): "How we talk about how we talk: Communication theory in the public interest". Journal of Communication 55/4: 659-667.

Duncan, Barry/Miller, Scott D./Wampold, Bruce E./Hubble, Mark A. (eds.) (2010): The Heart and Soul of Change: Delivering what Works in Therapy. Washington/DC: American Psychological Association.

Edwards, Derek/Stokoe, Elizabeth (2007): "Self-help in calls for help with problem neighbors". Research on Language and Social Interaction 40/1: 9-32. doi: 10.1080/ 08351810701331208.

Elliot, Robert/Bohart, Arthur/Watson, Jeanne/Greenberg, Leslie (2011): “Empathy”. In: Norcross, John (ed.): Psychotherapy Relationships that Work. $2^{\text {nd }}$ edition. New York, Oxford University Press: 132-152.

Eurostat (2017, January 30): Internet access and use statistics - households and individuals [Eurostat Statistics Explained]. http://ec.europa.eu/eurostat/statistics-explained/index.php/ Internet_access_and_use_statistics_-_households_and_individuals\#Internet_use_by_indi viduals [28.08.2017]. 
Firth, Alan/Emmison, Michael/Baker, Carolyn (2005): Calling for Help: Language and Social Interaction in Telephone Helplines. Amsterdam/Philadelphia: Benjamins.

Fukkink, Ruben/Hermanns, Jo (2009): “Children's experiences with chat support and telephone support". Journal of Child Psychology and Psychiatry 50/6: 759-766. doi: 10.1111/j.1469-7610.2008.02024.x.

Garcia, Angela Cora/Baker Jacobs, Jennifer (1999): "The eyes of the beholder: Understanding the turn-taking system in quasi-synchronous computer-mediated communication". Research on Language and Social Interaction 32/4: 337-367. doi: 10.1207/S1532 7973rls3204_2.

Geller, Shari/Greenberg, Leslie (2002): “Therapeutic presence: Therapists' experience of presence in the psychotherapy encounter". Person-Centered \& Experiential Psychotherapies 1/1-2: 71-86. doi: 10.1080/14779757.2002.9688279.

Giles, David/Stommel, Wyke/Paulus, Trena/Lester, Jessica/Reed, Darren (2015): "Microanalysis of online data: The methodological development of "digital CA"'. Discourse, Context \& Media 7: 45-51. doi: 10.1016/j.dcm.2014.12.002.

Gordon, Cynthia/Luke, Melissa (2016): "Metadiscourse in group supervision: How school counselors-in-training construct their transitional professional identities". Discourse Studies 18/1: 25-43. doi: 10.1177/1461445615613180.

Hepburn, Alexa/Potter, Jonathan (2007): "Crying receipts: Time, empathy, and institutional practice". Research on Language and Social Interaction 40/1: 89-116. doi: 10.1080/08351810701331299.

Heritage, John/Sefi, Sue (1992): "Dilemmas of advice: Aspects of the delivery and reception of advice in interactions between health visitors and first time mothers". In: Drew, Paul/Heritage, John (eds.): Talk at Work: Interaction in Institutional Settings. Cambridge, Cambridge University Press: 359-419.

Hutchby, Ian/Wooffitt, Robin (2008): Conversation Analysis. $2^{\text {nd }}$ edition. Cambridge: Polity Press.

Kiesler, Donald (1996): Contemporary Interpersonal Theory and Research: Personality, Psychopathology, and Psychotherapy. New York: Wiley.

King, Robert/Bambling, Matthew/Lloyd, Chris/Gomurra, Rio/Smith, Stacy/Reid, Wendy/Wegner, Karly (2006a): "Online counselling: The motives and experiences of young people who choose the Internet instead of face to face or telephone counselling". Counselling and Psychotherapy Research 6/3: 169-174. doi: 10.1080/14733140600848179.

King, Robert/Bambling, Matthew/Reid, Wendy/Thomas, Ian (2006b): "Telephone and online counselling for young people: A naturalistic comparison of session outcome, session impact and therapeutic alliance". Counselling and Psychotherapy Research 6/3: 175-181. doi: 10.1080/14733140600874084.

Kinnell, Ann Marie/Maynard, Douglas (1996). “The delivery and receipt of safer sex advice in pretest counseling sessions for HIV and AIDS". Journal of Contemporary Ethnography 24/4: 405-437. doi: 10.1177/089124196024004002.

Lamerichs, Joyce/Stommel, Wyke (forthcoming): “Online talk about mental health". Oxford Research Encyclopedia.

Lietaer, Germain (1993): “Authenticity, congruence, and transparency”. In: Brazier, David (ed.): Beyond Carl Rogers. London, Constable: 17-46. 

interactional trouble in online chat counseling

Limberg, Holger/Locher, Miriam A. (eds.) (2012): Advice in Discourse. Amsterdam: Benjamins.

Markman, Kris (2009): “So what shall we talk about': Openings and closings in chat-based virtual meetings". Journal of Business Communication 46/1: 150-170. doi: 10.1177/ 0021943608325751.

Meredith, Joanne/Stokoe, Elizabeth (2014): "Repair: Comparing Facebook 'chat' with spoken interaction". Discourse \& Communication 8/2: 181-207. doi: 10.1177/1750481313510815.

Peräkylä, Anssi/Vehviläinen, Sanna (2003): "Conversation analysis and the professional stocks of interactional knowledge”. Discourse \& Society 14/6: 727-750. doi: 10.1177/ 09579265030146003.

Raclaw, Joshua (2008): "Two patterns for conversational closings in instant message discourse". Colorado Research in Linguistics 21/1: 34-54.

Richards, Derek/Viganó, Noemi (2013): "Online counseling: A narrative and critical review of the literature". Journal of Clinical Psychology 69/9: 994-1011. doi: 10.1002/jclp.21974.

Rochlen, Aaron/Zack, Jason/Speyer, Cedric (2004): "Online therapy: Review of relevant definitions, debates, and current empirical support". Journal of Clinical Psychology 60/3: 269-283. doi: 10.1002/jclp.10263.

Sacks, Harvey (1992): Lectures on Conversation. Vol. 1, 2. Oxford, England: Blackwell.

Schalken, Frank/Blankers, Matthijs/Donker, Tara/Duinstra, Uilke/Van Gemert, Marieke/Van Hoogenhuyze, Carolien (eds.) (2013): Handbook Online Counselling [Handboek online hulpverlening]. Houten: Bohn Stafleu van Loghum.

Schegloff, Emanuel (1992): "Repair after next turn: The last structurally provided defense of intersubjectivity in conversation". American Journal of Sociology 97/5: 1295-1345. doi: $10.1086 / 229903$.

Schiffrin, Deborah (1980): "Meta-talk: Organizational and evaluative brackets in discourse". Sociological Inquiry 50/3-4: 199-236. doi: 10.1111/j.1475-682X.1980.tb00021.x.

Stommel, Wyke/Te Molder, Hedwig (2015): "Counselling online and over the phone: When pre-closing questions fail as a closing device". Research on Language and Social Interaction 48/3: 281-300.

Tannen, Deborah (1994): “The relativity of linguistic strategies: Rethinking power and solidarity in gender and dominance". In: Tannen, Deborah (ed.): Gender and Discourse. New York, Oxford University Press: 19-52.

Van Gemert, Marieke/Van Hoogenhuyze, Carolien (2013): "Online communiceren via synchroon contact". In: Schalken, Frank/Blankers, Matthijs/Donker, Tara/Duinstra, Uilke/Van Gemert, Marieke/Van Hoogenhuyze, Carolien (eds.): Handbook Online Counselling [Handboek online hulpverlening]. Houten, Bohn Stafleu van Loghum: 79-94.

Van Nijnatten, Carolus (2006): "Meta-communication in institutional talks". Qualitative Social Work 5/3: 333-349. doi: 10.1177/1473325006067364.

Verschueren, Jef (1999): Understanding Pragmatics. New York: Oxford University Press.

Whalen, Jack/Zimmerman, Don/Whalen, Marilyn (1988): "When words fail: A single case analysis". Social Problems 35/4: 335-362. doi: 10.2307/800591. 


\section{Bionotes}

Margot Jager is currently working as a Postdoc Researcher in Public Health Research at the University Medical Center Groningen. Her research focuses on client-professional interaction and eHealth, using both quantitative and qualitative methods. She has been/is involved in research on therapeutic interaction, medical interaction, and eHealth applications for community-living older adults. Last year she worked as a Postdoc Researcher at the Center for Language Studies, Radboud University Nijmegen, where she studied online chat counselling. Margot has lectured in several BA- and MA-programs including Dutch Language and Culture, Communication and Information Sciences, and Social Sciences. She has published research articles in international peer-reviewed journals like Language in Society and Patient Education and Counseling .

Wyke Stommel is an Assistant Professor in Language and Communication at the Center for Language Studies, Radboud University Nijmegen. Her research interest lies in institutional interaction, both face-to-face and mediated interaction, using Conversation Analysis and related approaches. She has been/is involved in studies of (online) counselling and service, online support groups, (video-mediated) medical consultations and police interrogations. Wyke lectures in several BA- and MA-programs including Dutch Language and Culture, Communication and Information Sciences and Linguistics. She is one of the initiators of the MOOD (Microanalysis of Online Data) network that aims to develop CA as a method for the analysis of "digital" interaction, like online chat and e-mail counselling and forum discussions. She has published research articles in journals like Research on Language and Social Interaction, Discourse Studies and Journal of Pragmatics. 